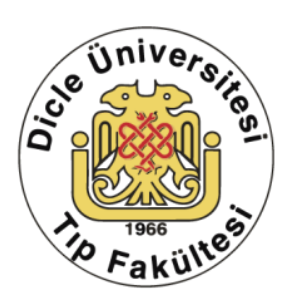

\title{
Böbrek Transplantasyonu Verilerimiz; Diyarbakır'da Tek Merkez Deneyimi
}

\author{
1 SBÜ Gazi Yaşargil EAH Organ Nakli Merkezi, Genel Cerrahi, Diyarbakır, Türkiye \\ 2 SBÜ Gazi Yaşargil EAH İffeksiyon Hastalıklarl, Diyarbakır, Türkiye \\ 3 Diyarbakır Cocuk Hastalıkları Hastanesi, Çocuk Nefrolojisi, Diyarbakır, Türkiye \\ 4 Dicle Üniversitesi Organ Nakli Merkezi, Genel Cerrahi, Diyarbakır, Türkiye
}

Nurettin Ay¹, Şafak Kaya² ${ }^{2}$ Neslihan Çiçek ${ }^{3}$, Mehmet Veysi Bahadır ${ }^{4}$

Geliş: 27.01.2017 Revizyon: 03.05.2017 Kabul: 04.05.2017

\section{Özet}

Amaç: Bu çalışmanın amacı, ülkemizde 1975 yılında uygulamaya geçen ve hastanemizde ancak 2012 yılında başlatılan böbrek nakli programının sonuçlarını retrospektif olarak değerlendirmektir.

Yöntemler: Eylül 2012-Aralık 2016 tarihleri arasında Organ Nakli Merkezimizde böbrek transplantasyonu uygulanan 115 hasta demografik veriler, immunsüpresif protokolü, rejeksiyon durumu, greft kaybı, hasta kaybı, postoperatif cerrahi komplikasyonlar, BK viremi (BKV) ve nefropatisi (BKN), cytomegalovirus (CMV) infeksiyonu, tüberküloz (TBC) ve posttransplant malignensi açısından değerlendirildi.

Bulgular: On iki olguya $(\% 10,4)$ kadavradan, 103 olguya $(\% 89,6)$ canlı donörden böbrek transplantasyonu uygulandı. Alıcıların ve donörlerin ortalama yaşı sırası ile 34.65 (12-68) ve 42 (23-72) idi. Erkek/Kadın oranı alıcı ve donörlerde sırası ile 65/50 ve 48/67 idi. Postoperatif median ve çeyreklerarası aralık (ÇAA) taburculuk kreatini 1.03 [0.55-1.48] mg/dl idi. Yedi (\%6) olgu akut rejeksiyon tanısı aldı. Dört olguda $(\% 3,4)$ greft kaybı gözlendi. Mortalite gözlenmedi.

Sonuç: Böbrek transplantasyonu programımız gelişim aşamasındadır. Ancak kısa dönem sonuçlar literatür ile uyumlu görünmektedir. Uzun süreli takip sonuçları ile daha anlamlı sonuçlar elde edilebilir.

Anahtar kelimeler: Böbrek nakli, tek merkez, rejeksiyon, greft kaybı

DOI: $10.5798 /$ dicletip.319771

Yazışma Adresi / Correspondence: Nurettin Ay, SBÜ Gazi Yaşargil EAH, Organ Nakli Merkezi e-mail:nurettinay77@hotmail.com 


\title{
A Single Centre Experience of Renal Transplantation in Diyarbakir
}

\begin{abstract}
Objectives: The aim of this study is to retrospectively evaluate the results of the transplantation program that started in 2012 in our hospital.

Methods: We examined the demographic variables, immunosuppressive protocols, rejection rates, graft survival, mortality, postoperative surgical complications, BK viremia (BKV) and BK virus-assoiciated nephropathy (BKN), cytomegaloviruse (CMV) infection rates, tuberculosis (TBC) rates and posttransplant malignancy rates of 115 patients who received kidney transplant in our transplantation center between September 2012 and December 2016.

Results: Twelve (10.4\%) patients received kidney from cadaver donors and 103 (89.6\%) paients received kidney from living donors. The Mean donor age was 42 (23-72) and the mean recipient age was 34.65 (12-68). Male to female ratio was $65 / 50$ for the recipients and $48 / 67$ for the donors. Median discharge creatinine was $1.03 \mathrm{mg} / \mathrm{dl}$ [interquartile range $=0.55-1.48$ ]. Seven patients (6\%) suffered from acute rejection and graft loses occurred in four (3.4\%) patients. There was no mortality.

Conclusion: Our kidney transplantation program is in the developmental stage. However, short-term outcomes are consistent with the literature. More meaningful results can be obtained with long-term follow-up results.
\end{abstract}

Keywords: renal transplantation, single centre, rejection, graft loss

\section{GíRiş}

Böbrek transplantasyonu son dönem böbrek yetersizliği (SDBY) için en ideal tedavi yöntemidir ${ }^{1}$. Türkiye'de canlıdan canlıya böbrek nakli, ilk olarak 1975 yllında, kadavradan böbrek nakli ise 1978 yllında gerçekleştirildi. Ylllar içinde organ nakline desteğin bir devlet politikası olması ile organ nakli sayısı giderek artış gösterdi. Türkiye Organ, Doku Nakli ve Diyaliz Hizmetleri Daire Başkanlığı verilerine göre 2016 yılında 3418 böbrek nakli gerçekleştirildi ${ }^{2}$. Diyarbakır'da organ nakli gelişim süreci ilk olarak, sosyoekonomik nedenlerden dolayı geç olsa da, 2011 yılında Dicle Üniversitesi Tıp Fakültesinde başladı. Organ nakli merkezimiz, 2012 yllında böbrek nakli programına başladı. $\mathrm{Bu}$ çalışmanın amacı ülkemizde 1975 yılında başlayan ve hastanemizde ancak 2012 yllında başlatılan böbrek nakli programının sonuçlarını değerlendirmektir.

\section{YÖNTEMLER}

Çalışmaya Eylül 2012-Aralık 2016 tarihleri arasında Organ Nakli Merkezimizde böbrek transplantasyonu uygulanan 115 hasta dahil edildi. Çalışmamız retrospektif bir çalışma olup 2008 Helsinki deklarasyonu ilkelerine uygun olarak hazırlanmıştır. Tüm hastalardan bilgilendirilmiş onam alındı. Ayrıca çalışmada kullanılacak veriler için hastanenin ilgili biriminden izin alındı. Yüz üç olguya canlı donörden, 12 olguya kadavra donörden böbrek transplantasyonu uygulandı. Demografik veriler, immunsüpresyon protokolü, rejeksiyon durumu, greft kaybi, hasta kaybı, postoperatif cerrahi komplikasyonlar, BKV ve BKN, CMV infeksiyonu, tüberküloz ve posttransplant malignensi durumu retrospektif olarak değerlendirildi (Tablo 1, 2).

\section{İmmünsüpresyon ve profilaksi}

İndüksiyon tedavisi olarak basiliksimab (20 $\mathrm{mg} /$ gün; operasyon günü ve postoperatif 4.günde) ve anti-timosit globulin (ATG; yüksek riskli hastalar için: operasyon esnasında 3 $\mathrm{mg} / \mathrm{kg}$ ve postoperatif 1 . ve 2 . günler 1.5 $\mathrm{mg} / \mathrm{kg}$ kullanıldı. Metilprednizolon intraoperatif $1000 \mathrm{mg}$ uyguland. Takip eden günlerde kademeli olarak azaltılarak postoperatif 6 . günde $20 \mathrm{mg}$ oral prednizolona geçildi. Birinci yılın sonunda oral prednizolon 
dozu 5mg/gün'e kadar düşürüldü. Kalsinörin inhibitörleri (CNI; takrolimus: 0.1-0.15 $\mathrm{mg} / \mathrm{kg} /$ gün ve siklosiporin: 6-8 mg/kg/gün) ve mikofenolat mofetil ( MMF; 2g/gün, iki doza bölünerek) ya da mikofenolat sodyum (MMF; $1440 \mathrm{mg} / g u ̈ n$, iki doza bölünerek ) immunsüpresyonun idamesinde kullanıldı. Çocuklarda MMF dozu $600 \mathrm{mg} / \mathrm{m} 2$, iki bölünmüş doz olarak verildi. Everolimus (5. günde $\mathrm{MMF}$ ile değiştirilerek), miss-match sayısı 2 ve altı olan bazı olgularda tacrolimus ile birlikte kullanılmak üzere tedaviye eklendi. Everolimus hedef düzeyi tacrolimus ile birlikte 4-8 mg/dl aralığında tutulmaya çalıșıldı. Ancak CNI'leri nedeniyle trombotik trombositopenik purpura (TTP) geliştiği düşünülen olgularda everolimus, CNI'nin yerine kullanıldı ve hedef düzeyi 8-10 $\mathrm{mg} / \mathrm{dl}$ aralığında tutulmaya çalışıldı. Pneumocytis jirovecii ve CMV proflaksisi için postoperatif altıncı aya kadar sırası ile trimetoprim/sülfometoksazol (400mg/gün) ve valgansiklovir (450mg/gün) kullanıldı. Gecikmiş greft fonksiyonu (GGF), posttransplant dönemde diyaliz ihtiyacının olması olarak tanımlandı. Greft kaybı alıcının greft yetersizliği nedeniyle diyalize geri dönüşü olarak tanımlandı. Akut rejeksiyon tanısı böbrek biyopsisi ile konuldu. Akut hücresel rejeksiyon, rejeksiyonun şiddetine bağlı olarak, intravenöz pulse metilprednizolon ve/veya ATG ile tedavi edildi. Akut humoral rejeksiyon tanısı konulan veya eşlik eden olgularda gün aşırı plazmaferez + intravenöz immunoglobulin (İíG) ile tedavi edildi.

\section{Cerrahi teknik}

Donör nefrektomiler laparoskopik (transabdominal) ve açık yöntemle uygulandı. Böbrek nakli programımızın ilk dönemlerinde deneyim eksikliği nedeniyle donör nefrektomiler açık uygulandı. Ancak deneyim kazanılmasıyla birlikte sol donör nefrektomiler (anatomik olarak uygun ise) laparoskopik olarak gerçekleştirildi. Sağ donör nefrektomilerde, renal venin kısa olması nedeniyle kısa ve uzun vadede gelişebilecek olası komplikasyonlar nedeniyle, açık yöntem uygulandı. Greft, tip I DM olmayan ve retransplantasyon olmayan olgularda sağ alt kadrana yerleştirildi. Renal arter tek ise 6/0 prolen ile eksternal iliak arter (EİA) veya common iliak artere (CIA) uç-yan anastomoz edildi. Multipl arteri bulunan olgularda 7/0 prolen kullanıldı. Renal ven ile eksternal iliak ven 6/0 prolen ile uç-yan anastomoz yapıldı. Üreteroneosistostomi (ÜNS), ekstravezikal teknik ile (Lich-Gregoir) gerçekleştirildi. Double-j-stend olguların tümünde kullanıldı. Postoperatif 5. günde üriner kateter çekildi. DJS, postoperatif 4. haftada lokal anestezi altında, sistoskopi eşliğinde çekildi.

Tablo 1: Böbrek nakli uygulanan olguların tanımlayıcı verileri. ATG: Antitimosit globülin; Med+ÇAA: medyan + çeyreklerarası

\begin{tabular}{l}
\hline Hasta sayısı n=115 \% \\
\hline Cinsiyet E/K \\
Alıcı 65/50 \\
Donör 67/48 \\
Yaş (yıl) \\
Alıcı 34,6 (12-68) \\
Donör 42 (23-72) \\
Med + ÇAA takip süresi ( ay) 27[6-46] \\
Donör tipi \\
Canlı 103 (\%89,6) \\
Kadavra 12 (10,4) \\
Preemptif 41 (\%36) \\
Donör operasyonu \\
Açı nefrektomi 75 (\%71,4) \\
Laparoskopik nefrektomi 30 (\%28,6) \\
İndüksiyon \\
Yok 15 (\%13) \\
ATG 61 (\%53) \\
Basiliksimab 39 (\%34) \\
\hline
\end{tabular}

\section{Takip}

Bütün hastalar renal fonksiyonlar, idrar yolu enfeksiyonu (IYE), BKV ve BKN, hematolojik ve biyokimyasal parametreler açısından yakın takip edildi. Ateş, serum kreatin artışı, yükselmiş C-reaktif protein (CRP) ve idrar kültüründe $>100000 \quad \mathrm{koloni} / \mathrm{ml}$ bakteri bulunması IYYE ile ilişkili bulundu. BK virüs taraması (polimeraz zincir reaksiyonu ile) 
postoperatif birinci ayda başlandı (ilk 3 ay, ayda bir; sonraları 3 ayda bir) ve iki yıl boyunca devam edildi. Rejeksiyon tedavisi gören olgularda bu protokol tekrarland. CMV taraması postoperatif 6 . ayda başlandı ve 3 ayda bir tekrarlandı. BK virüs takiplerinde iki veya daha fazla ardışı ölçümde >500 kopya/ml tespit edilen olgularda BKV tanısı konuldu. Viral yük > 5000 kopya/ml olan olgularda immunsüpresyon dozunda azaltma uygulandı. İlk olarak MMF dozu azaltıldı veya kesildi. Vireminin devam etmesi durumunda prednizolon dozu azaltıldı veya kesildi. Mevcut vireminin devam etmesi veya BKN gelişmesi durumunda tüm immunsüpresif ilaçlar kesildi. BKN gelişen olgularda siklosporin, leflunomid ve IVIGG tedavisi planlandı.

Tablo 2: Böbrek transplantasyonu sonrası takiplerde alıcıların klinik sonuçları. KAN: Kronik allograft nefropatisi; BKN: BK nefropatisi; RAP: Renal arter psödoanevrizması; GGF: Gecikmiş greft fonksiyonu; CMV: Sitomegalovirüs; BKV: BK viremi; TBC: Tüberküloz

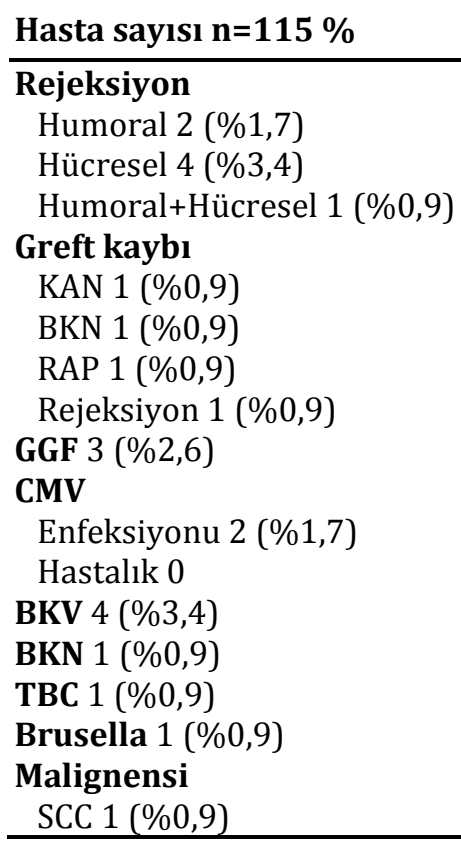

\section{İstatiksel Analiz}

İstatiksel analizler ve tanımlayıcı veriler SPSS versiyon 16 yazılımı kullanılarak yapıldı. Değişkenlerin normal dağılıma uygunluğu analitik yöntemlerle incelendi. Tanımlayıcı veriler normal dağılmayan değişkenler için medyan ve çeyrekler arası aralık kullanılarak verildi. Gruplar arasında (preemptif ve nonpreemptif gruplar arasında greft kaybı karşılaştırıldı) sıklıklar bakımından fark Kikare testi ile karşılaştırıldı. P-değerinin $<0.05$ olduğu durumlar istatiksel olarak anlaml olarak değerlendirildi.

\section{BULGULAR}

Eylül 2012-Aralık 2016 tarihleri arasında böbrek transplantasyonu uygulanan 115 olgu retrospektif olarak değerlendirildi. Olguların 12'sine (\%10.4) kadavradan, 103'ü (\%89.6) canlı vericili böbrek transplantasyonu uygulandı. Bilinen en sık böbrek yetersizlik nedeni hipertansiyondu (Tablo 3). Alıciların ve canlı donörlerin ortalama yaşı sırası ile 34.65 (12-68) ve 42 (23-72) idi. Dokuz olgu çocuk hasta idi. Erkek/Kadın oranı alıcı ve donörlerde sırası ile $65 / 50$ ve $67 / 48$ idi. Median ve çeyrekler arası aralık (ÇAA) takip süresi 27(646) ay idi. Ortalama hastanede kalış süresi 8 (532) gündü. Postoperatif median ve ÇAA taburculuk kreatini 1.03(0.55-1.48) mg/dl idi. Preemptif böbrek transplantasyonu 41 (\%36) olguya uyguland. İndüksiyon tedavisi olarak 61 olguya ATG, 39 olguya basiliksimab uygulandı. On beş olguya indüksiyon tedavisi uygulanmadı. İki olguya siklosporin + MMF + prednisolon, 6 olguya everolimus + takrolimus + prednizolon protokolü uygulandı. Diğer tüm olgularda takrolimus $+\mathrm{MMF}+$ prednizolon protokolü uygulandı. Ancak bu protokol uygulanan iki olguda gelişen TTP (CNI kaynaklı olduğu düşünülerek) gelişmesi üzerin everolimus + MMF + prednizolon protokolüne geçildi. TTP gelişen olgular plazmaferez ile tedavi edildi. Bir olguda skuamoz hücreli kanser gelişti. $\mathrm{Bu}$ olguya tümör eksizyonu uygulandı ve takrolimus, everolimus ile değiştirildi. Biyopsi ile kanıtlanmış 7 olguda akut rejeksiyon tanısı konuldu. Bunların 3'ünde humoral rejeksiyon eşlik etmekteydi. Humoral rejeksiyon gelişen bir olguda greft kaybı gerçekleşti. $\mathrm{Bu}$ olguda preoperatif yapılan 
immünolojik değerlendirmede kompleman bağıml (CDC), akım sitometrisi ve donör spesifik antkor tarama ve tanımlama yöntemlerinde herhangi bir antikor tespit edilmemişti. Toplamda 4 olguda greft kaybı gözlendi. Diğer greft kaybı nedenleri kronik allograft nefropatisi (kadavra donörden), renal arter psödoanevrizması (kadavra donörden) ve BKN'ydi. GGF, üç olguda gözlendi. Bunlardan ikisinde greft kaybı gözlendi. Postoperatif dönemde 1 olguda kanama, 1 olguda renal arter psödoanevrizması, 1 olguda subkapsüler hematom, 1 olguda ÜNS'de stenoz ve 5 olguda lenfosel gelişti. Lenfosel öncelikli olarak perkutan olarak drene edilmeye çalışıldı. Yanıt vermeyen 3 olguya laparoskopik fenestrasyon uygulandı. Takipler esnasinda 2 olguda CMV enfeksiyonu gözlendi. Ancak hiçbir olguda CMV hastalığı gözlenmedi. Bu olgularda MMF dozu azaltılarak tedaviye oral valgansiklovir eklendi. Her iki olguda da CMV negatifleşti. Üç olguda BKV tespit edildi. Ancak bir olguda immunsüpresyon kesilmesi ve IVİG tedavisine rağmen BKN sonrasında greft kaybı gelişti. Bir olguda takipleri süresince brusella pnömonisi, milier TBC gözlendi.

Tablo 3: KBY etyolojileri. HT: Hipertansiyon; PKBH: Polikistik Böbrek Hastalığı; VUR: Vezikoüreteral Reflü

\begin{tabular}{lc}
\hline KBY etyolojisi & Hasta sayısı n=115 \% \\
\hline Bilinmiyor & $54(\% 46,9)$ \\
Diyabetes mellitus & $8(\% 6,9)$ \\
HT & $30(\% 26)$ \\
PKBH & $2(\% 1,7)$ \\
VUR & $4(\% 3,4)$ \\
Nefrolitiyazis & $7(\% 6,1)$ \\
Nefrotik sendrom & $6(\% 5,2)$ \\
Nörojenik mesane & $2(\% 1,7)$ \\
Nefronofitizis & $2(\% 1,7)$ \\
\hline
\end{tabular}

\section{TARTIŞMA}

Böbrek transplantasyonu, seçilmiş olgular için son dönem böbrek yetersizliğinin en seçkin yöntemidir. Başarılı bir böbrek transplantasyonu, diyaliz ile karşılaştırıldığında gerek yaşam beklentisi gerekse yaşam kalitesi açısından daha üstündür ${ }^{3-5}$. Simforoosh ve ark. yaptıkları çalışmada, 1984-2015 yılları arasında böbrek transplantasyonu olan 3716 olguyu değerlendirmişlerdir. Bu çalışmada 3, 10 ve 25 yıllık greft ve hasta sağ kalımları sırası ile $\% 77,4, \% 54,9, \% 31,5$ ve $\% 88,5, \% 80,2$, \%67,9 bulunmuştur 6 . Ali ve ark. Irak'ta, tek bir merkezde, beş ylllık transplantasyon verilerini değerlendirdikleri çalışmalarında bir yıllık greft ömrünü \%94,4; üç ylllık greft ve hasta sağ kalımı sırası ile \%91 ve 90 bulmuşlardır. Yine aynı çalışmada beş yıllık greft ve hasta sağ kalımı sırası ile \%87,1 ve $\% 88$ bulunmuştur? Çalışmamızda median takip süresi 27 aydı. Bir yıllık greft ve hasta sağ kalımımız sırası ile $\% 98,3$ ve $\% 100$ idi. Tüm hastalarımızın takipleri süresince greft ve hasta sağ kalımı ise sırası ile \%96,5 ve \%100'dü. Greft ve hasta sağ kalım oranlarımızın erken dönemde Simforosh ve ark. verilerinden daha yüksek olması muhtemelen gelişen immunsupresyon protokolleri ve immünolojideki gelişmeler olabilir. Sayın ve ark. böbrek transplatasyonu uygulanan 100 olguyu değerlendirdikleri çalışmada olguları preemptif ve nonpreemptif olarak karşılaștırdılar. Otuz yedi olguya preemptif, 63 olguya nonpreemptif böbrek transplantasyonu yapıldı. Her iki grup arasında 5 yıllık greft ve hasta sağ kalımı açısından istatiksel olarak anlamlı bir fark bulmadılar8. Çalışmamızda 4 olguda greft kaybı gözlendi. Preemptif böbrek nakli yapılan 41 olgudan biri BKN nedeniyle greft kaybı ile sonuçlandı. Greft sağ kalımı açısından preemptif ve non-preemptif grup arasında istatiksel olarak anlaml bir fark bulunmadı ( $p>0.05)$. Ancak hemodiyalizin kardiyovasküler sistem üzerindeki olumsuz etkileri nedeniyle, bu iki grubun karşılaştırılabilmesi için daha uzun süreli takip süresine ihtiyacımız bulunmaktadır. Garcia ve ark. tarafından 2004-2012 yılları arasında 175 hastaya böbrek transplantasyonu uygulandı. Olguların \%14,3'ünde ilk bir yıl içerisinde hücresel rejeksiyon gözlendi. $\mathrm{Bu}$ olguların $\% 46$ 'sı ilk 6 ay içerisinde gözlendi ${ }^{9}$. Çalışmamızda 7 (\%6) olguda akut rejeksiyon gözlendi. Sadece 1 olguda bir yıldan sonra 
gözlendi. $\mathrm{Bu}$ olguya humoral rejeksiyon nedeniyle plazmaferez + IVİG protokolü uyguland. Krajewski ve ark. postoperatif ürolojik komplikasyonları değerlendirdikleri çalışmalarında 2008-2014 yılları arasındaki 460 olguyu değerlendirdiler. Üreteral stenoz, lenfosel, nefroüreterolitiyazis ve üretral stenoz sırası ile 38 (\%8,2), 10 (\%2), 5 (\%1) ve $5(\% 1)$ olgu tanı aldı10. Çalışmamızda bir olguda ÜNS stenozu, $5(\% 4,3)$ olguda ise lenfosel gözlendi. BKN, böbrek transplantasyonu sonrası genellikle olguların \%5-10'unda gözlenir ${ }^{11}$. Postoperatif takiplerimizde $3(\% 2,6)$ olguda BKV gözlendi. Bir olguda immunsüpresyon dozunun azaltılması ve ciprofloksasin ve IVİG tedavisine rağmen BKN gelişti ve greft kaybı ile sonuçland. İnvazif aspergillozis posttransplantasyon dönemde \%0,5-4 sıklığında gözlenir ve mortalitesi \%40-70 aralığında değişir. Böbrek transplantasyonu uygulanan ve takiplerinde $\mathrm{BKN}+\mathrm{CMV}$ infeksiyonu + invazif aspergillozis (greft böbrek posteriorunda lokule abseden mikrobiyolojik ve patolojik olarak tanı konuldu) gelişen bir olgumuza greft nefrektomi ve abse drenajı uygulandı.

Sonuç olarak, organ nakli merkezi bünyesindeki böbrek transplantasyonu programı gelişim aşamasındadır. Ancak kısa dönem sonuçlar literatür ile uyumlu görünmektedir. Uzun süreli takip sonuçları ile daha anlamlı sonuçlar elde edilebilir.

Çıkar Çatışması Beyanı: Yazarlar çıkar çatışması olmadığını bildirmişlerdir.

Finansal Destek: $\mathrm{Bu}$ çalışma her hangi bir fon tarafından desteklenmemiştir.

Declaration of Conflicting Interests: The authors declare that they have no conflict of interest.

Financial Disclosure: No financial support was received.

\section{KAYNAKLAR}

1. Ahmad N, Ahmed K, Khan MS, et al. Living-unrelated donor renal transplantation: an alternative to livingrelated donor transplantation? Ann R Coll Surg Engl. 2008; 90:247-50.

2. Türkiye Organ, Doku Nakli ve Diyaliz Hizmetleri Daire Başkanlı̆̆ı. https://organ.saglik.gov.tr/0TR/70Istatistik/ ORGAN_010103.aspx

3. Suthanthiran M, Strom TB. Renal transplantation. N Engl J Med. 1994; 331:365-76.

4. Port FK, Wolfe RA, Mauger EA, Berling DP, Jiang K. Comparison of survival probabilities for dialysis patients vs cadaveric renal transplant recipients. JAMA. 1993; 270: 1339-43.

5. Ay N, Anıl M, Alp V, et al. Evaluation of Quality of Life Early and Late After Kidney Transplantation. Ann Transplant. 2015; 20: 493-499 DOI: 10.12659/ AOT.895139

6. Simforoosh N, Basiri A, Tabibi A, et al. Living Unrelated Versus Related Kidney Transplantation: A 25-Year Experience with 3716 Cases. Urol J. 2016 Mar 5; 13: 2546-51.

7. Ali A. A, Al-Saedi AJ, Al-Mudhaffer AJ, et al. Five years renal transplantation data: Single-center experience from Iraq. Saudi J Kidney Dis Transpl. 2016 Mar;27: 341-7. doi: 10.4103/1319-2442.178559.

8. Sayin B, Colak T, Tutal E, et al. Comparison of preemptive kidney transplant recipients with nonpreemptive kidney recipients in single center: 5 years of follow-up. Int J Nephrol Renovasc Dis. 2013; 6:95-9. doi: 10.2147/IJNRD.S42042. Print 2013.

9. García $\mathrm{P}$, Huerfano M, Rodríguez $\mathrm{M}$, et al. Acute Rejection in Renal Transplant Patients of a Hospital in Bogota, Colombia. Int J Organ Transplant Med. 2016; 7:161-6.

10. Krajewski W, Dembowski J, Kołodziej A, et al. Urological complications after renal transplantation -a single centre experience. Cent European J Urol. 2016; 69:306-11.

11. Josephson MA, Williams JW, Chandraker A, et al. Polymavirus-associated nephropathy: update on antiviral strategies. Transplant Infect Dis. 2006; 8:95101.

12. Singh N, Paterson DL. Aspergillus infections in transplant recipients. Clin Microbiol Rev. 2005;18 :4469. 